\title{
Botany
}

\section{Is the Common Teasel (Dipsacus fullonum) Carnivorous or was Francis Darwin Wrong?}

\begin{tabular}{|c|c|}
\hline Journal: & Botany \\
\hline Manuscript ID & $c j b-2019-0008 . R 1$ \\
\hline Manuscript Type: & Article \\
\hline $\begin{array}{r}\text { Date Submitted by the } \\
\text { Author: }\end{array}$ & 17-Mar-2019 \\
\hline Complete List of Authors: & $\begin{array}{l}\text { KRUPA, JAMES; University of Kentucky, Biology; University of Kentucky, } \\
\text { University of Kentucky } \\
\text { Thomas, J. Matthew; University of Kentucky, Department of Kinesiology } \\
\text { and Health Promotion }\end{array}$ \\
\hline Keyword: & $\begin{array}{l}\text { Botanical Carnivory, Dipsacus fullonum, Common teasel, Seed } \\
\text { production, Germination }\end{array}$ \\
\hline $\begin{array}{r}\text { Is the invited manuscript for } \\
\text { consideration in a Special } \\
\text { Issue? : }\end{array}$ & Not applicable (regular submission) \\
\hline
\end{tabular}

\section{SCHOLARONE \\ Manuscripts}




\title{
Is the Common Teasel (Dipsacus fullonum) Carnivorous or was Francis Darwin Wrong?
}

\author{
James J. Krupa ${ }^{1 *}$ and J. Matthew Thomas \\ ${ }^{1}$ Department of Biology, University of Kentucky, Lexington, Kentucky, 40506-0225. \\ ${ }^{2}$ Department of Kinesiology and Health Promotion, University of Kentucky, Lexington, \\ Kentucky, 40506-0219. \\ *For correspondence. E-mail bio149@uky.edu
}


Abstract: Francis Darwin first suggested common teasel (Dipsacus fullonum), a biennial species, might be a carnivorous plant. He suggested this species acquires nutrients from insects that drown in water-holding cups formed at the base of leaves that surround stems. Since then, other biologists have made the same claim. To test this we addressed the question: does adding invertebrates as supplemental nutrients to water-filled cups of $D$. fullonum influence reproduction or are nutrients only obtained from the soil? We performed two factorial designed experiments (high-nutrient soil vs low-nutrient soil) $\mathrm{x}$ (fed vs control) to test this. Fed treatments involved either crickets or liquefied animal solution. We performed a third experiment where teasel plants were grown in nutrient deficient standard carnivorous plant soil mix to determine if prey supplement influenced growth and reproduction. These experiments revealed that soil nutrients alone influence growth and reproduction. More seeds were produced by plants grown in high-nutrient soil; while curiously, a higher percentage of seeds germinated from plants grown in low-nutrient soil. When teasel rosettes were grown in carnivorous plant soil, plants did not grow, produce stems, or flower even with animal solution. Thus we found no evidence suggesting common teasel is carnivorous.

Key Words: Botanical carnivory, Dipsacus fullonum, common teasel, seed production, germination, soil nutrients. 


\section{Introduction}

Carnivorous plants are most simply defined "...as those plants which use entrapped animal tissues for their nutrients" (Juniper et al. 1989). Botanical carnivory has been of fascination for centuries, and was studied in detail by Charles Darwin (1875) who first determined carnivorous plants captured prey to acquire nutrients. Francis Darwin (1877) first demonstrated that providing insects to leaves of the sundew Drosera rotundifolia led to plants producing more leaves and seeds than plants not given insects. Kellerman and von Raumer, (1878) and Büsgen (1883) provided corroborating support for this in the same species. Ellison (2006) reviewed 29 studies since 1883 that demonstrated 17 species of carnivorous plants increased growth and reproduction when provided insects. More recently, Jennings et al. (2010) showed that increasing the amount of insect prey increased seed production in D. capillaris and Pavlovič et al. (2014) found captured prey increases photosynthetic efficiency in D. capensis.

Determining if a species is carnivorous is not always straight forward. Givnish et al. (1984) stated that two requirements are needed to be carnivorous. Plants must be able to absorb nutrients from dead animals resulting in an increase growth, survival, pollen production, and number of seeds produced; second, the plants exhibit an adaptation such as active attraction, capture, and digestion of prey. Juniper et al. (1989) defined the concept of the carnivorous syndrome as having six categories including the ability to attract prey, trap prey, retain prey, kill prey, digest prey, and absorb prey to acquire useful substances. Juniper et al. (1989) indicated not all carnivorous plants exhibit these six traits. More recently, Adlassnig et al. (2010) refined the carnivorous syndrome as having four components: (1) attraction of prey; (2) retention of prey with specialized leaves; (3) dissolve prey with digestive enzymes; and (4) uptake of soluble compounds. Plachno et al. (2009) felt that true carnivorous plants are simply those able to take 
up nitrogen, phosphorous, potassium, and magnesium from prey animals through their leaves. This is in essence what Charles Darwin first demonstrated in 1875.

Plants with some of the characteristics of carnivorous plants, but lacking other key characteristics exist. Givnish et al. (1984) defined plants that attract, capture, or digest prey for other purposes than acquiring nutrients as being protocarnivorous. Adlassnig et al. (2010) suggested any species lacking even one feature of carnivorous plants as protocarnivorous, which they considered as on the evolutionary path to true carnivory. Spomer (1999) and Darnowski et al. (2006) considered plants that trap prey but depend on assistance for digestion as protocarnivorous or subcarnivorous, while Spomer (1999) further suggested protocarnivorous species often have sticky leaves with proteinase activity.

Even in light of this clarification, questions remain whether many taxa are carnivorous, protocarnivorous, paracarnivorous, or subcarnivorous. Genera for which there has been uncertainty or contrasting opinion and evidence include: devil's claw (Ibicella, Proboscidea; Schnell 2002, Rice 2006, Plachno et al. 2009), shepard's purse (Capsella, Rice 2006), epiphytic liverwort (Colura, Schnell 2002; Rice 2006), teasel (Dipsacus, Darwin 1877; Christy 1923; Juniper et al. 1989; Schnell 2002; Rice 2006; Shaw and Shackleton 2011), bromeliads (Paepalanthus, Catopsis; Givnish 1984; Schnell 2002), cinquefoil (Potentilla, Spomer 1999), purple geranium (Geranium, Spomer 1999), passion flower (Passiflora, Rice 2006), and triggerplants (Stylidium; Darnowski et al. 2006; Nge and Lambers 2018).

Since Turner (1568) first examined teasel, Dipsacus has been of interest because its leaves form water-holding cups often filled with dead insects trapped in the water. This is similar to carnivorous taxa such as Heliamphora, Sarracenia, and Nepenthes. Francis Darwin (1877) examined anatomical features of $D$. sylvestris $(=D$. fullonum) suggesting possible 
botanical carnivory. He found protoplasmic filaments associated with glandular trichomes and concluded that these structures are for absorbing nitrogenous matter from rainwater (ammonia) or from decaying insects held in leaf cups. Darwin did not declare teasel to be carnivorous, but provided a compelling argument suggesting more data were needed. As a note at the end of Francis' publication, his father Charles commented: "To the best of my judgement, the whole case is a remarkable one, and well deserves the attention of physiologists." Francis Darwin intended to demonstrate that teasel growth and reproduction benefited from captured insects as he did with D. rotundifolia: “...teasel raised from seed under similar conditions will be divided into two lots, one half being starved and the other fed with insects or pieces of meat." There is no evidence he completed this experiment. Since 1877, teasel has been considered carnivorous by some biologists. Christy (1923) unequivocally argued that $D$. fullonum is carnivorous based on his observations that the water-holding cups typically contain large numbers of decaying insects and the presence of the filaments described by Darwin (1877). Juniper et al. (1989) did not consider Dipsacus carnivorous, while Schnell (2002) felt more investigation was needed. Most recently, Shaw and Shackleton (2011) experimentally manipulated D. fullonum comparing seed mass as percentage of above-ground biomass of the plant between fed and unfed plants grown in the field. They reported that fed teasel produced $30 \%$ greater seed mass than either plants from which insects were removed or from controls (plants left with normal accumulation of dead insects). These authors stated they provided the first empirical evidence that teasel benefits from botanical carnivory.

In 2008, we began a series of three greenhouse experiments examining botanical carnivory in D. fullonum. Because this is a biennial species, we focused on reproduction rather than growth in the first two experiments and growth in the third experiment. In these 
experiments, we addressed the question of whether soil nutrients, prey supplement, or a combination of the two increases the number of seeds produced per plant and the quality of seeds (as measured by percentage of seeds germinated). From this, our aim was to determine if the common teasel is carnivorous.

\section{Materials and Methods}

\section{Study Species}

Common teasel (Dipsacus fullonum) is native to Europe and Asia. It is common in Great Britain where it grows in forest clearings, steep slopes and along stream banks, road sides, banks of ditches, and hedge rows (Christy 1923). Common teasel is wide-spread, invasive, and nonnative in North America. In Kentucky, like in its native range, common teasel grows in diverse habitats. It can be found in very wet roadside ditches, along streams, and at the edges of wetlands. It also grows along very dry roadsides with little topsoil. Flowering occurs from May to August.

Dipsacus fullonum is a large, biennial herbaceous plant dying after it sets seed typically at the end of its second year. A vegetative rosette grows the first season after germination with flowering occurring in the second year if the rosette reaches at least $30 \mathrm{~cm}$ dia (Werner 1975). Flowers are within closely packed, bulbous spikes. Stems supporting flower spikes begin growing from the center of the rosette in the spring. Depending on habitat, many lateral stems grow off the stalk also producing flower spikes as the season progresses. Plants that grow in low, wet areas are capable of reaching $2.5 \mathrm{~m}$ (Krupa pers. obs., Schnell 2002) and producing over 200 flower spikes (Krupa pers. obs.). Stems, leaves, and spikes are extremely prickly. Leaves are elongate, pointed, and lack petioles. At each node, the two opposite leaves fuse at the 
base with the stem running through them. This results in leaves forming water-holding cups capable of retaining up to $250 \mathrm{ml}$ of water (Christy 1923).

\section{Experiment 1}

In May 2008, soil mixes were added to two, $16 \mathrm{~m}^{2}$ raised plots $0.3 \mathrm{~m}$ high located in an ambient greenhouse on the University of Kentucky campus where seasonal and daily temperatures fluctuate along with outside temperatures from periods of below freezing in the winter to $40{ }^{\circ} \mathrm{C}$ during summer days. This was a 2 × 2 factorial designed experiment (highnutrient soil vs low-nutrient soil) $\mathrm{x}$ (fed vs control). In the high-nutrient soil plot, a $3 \mathrm{~m}^{3}$ mixture of 1/3 manure, 1/3 compost and 1/3 top soil was added (Fig. 1). These were purchased from a local supplier. In the low-nutrient soil plot, a $3 \mathrm{~m}^{3}$ mixture of $1 / 3$ vermiculite, $1 / 3$ perlite, and 1/3 topsoil was added (Fig. 1). All teasel seeds were planted in a raised bed located in the greenhouse with standard commercial potting soil mix. In November 2008, 24 teasel rosettes greater than $40 \mathrm{~cm}$ dia were transplanted from the raised bed to the experimental plots. They were planted in four rows of 6 plants in each plot for a total of 48 plants. In each row three plants were randomly assigned as controls and three as fed. The soil was kept moist with soaker hoses over the winter and until 1 September 2009. Flower stems began to grow the third week of April 2009.

Beginning in the second week of May and for the next 10 weeks ending on 15 July, $15 \mathrm{ml}$ of deionized water was added to cups on the main stem of each fed and control plant. Old water was removed from the control plants each week. For the fed treatment, five small frozen crickets were added to a cup on the main stem once a week. The water and the crickets were left in the leaf cups for the entire experiment. Plants began to flower the first week of June and continued 
flowering until the end of August. At the end of September, all flower spikes were ripe and turning brown. They were removed from each plant and placed in separate, large paper bags then stored in a cool, dry laboratory. After harvest, soil samples were sent to the University of Kentucky (hereafter U. K.) Regulatory Services for analysis. Available potassium and phosphorus was determined using Mehlich III extraction on an ICP, and total nitrogen was determined by using an Elementar VarioMax.

Seeds were very difficult to remove from flower spikes requiring three steps of extraction and purification before counting. In June 2010, flower spikes were placed on a pad of corrugated rubber inside a metal tray and each spike was crushed with a wooden block wrapped with corrugated rubber. Seeds and debris were then sifted through an aluminum sieve with $19 \mathrm{~mm}$ x 2 mm oblong openings (Seedburo Equipment Company, Chicago, Illinois) to separate large pieces of debris from seeds and finer debris. Large pieces of spikes were crushed a second time and again sifted to remove any remaining seeds. Seeds mixed with finer debris were then sifted through a sieve with $9 \mathrm{~mm} \times 1.5 \mathrm{~mm}$ openings. The remaining debris was examined carefully for seeds before being discarded. The mixture of seeds and very fine debris was then separated using an air column seed separator (Seedburo Equipment Company). Finally, seeds were counted using an Agriculex model ESC-1 automatic seed counter (Agriculux Inc., Guelph, Ontario, Canada).

Percentage of seeds germinated was determined with standard viability tests conducted at the U. K. Regulatory Services. For each plant that produced seeds, four replicates each with 25 seeds were placed on two layers of filter paper and covered with Petri glass. Germination temperatures were $15^{\circ} \mathrm{C} / 25^{\circ} \mathrm{C}$ with a $16 \mathrm{~h}$ dark $/ 8 \mathrm{~h}$ light photoperiod. On day $7,14,21$, and 
28, seedling development was measured by presence of a radicle and green cotyledons. From this, percentage germination was obtained for seeds of each plant.

\section{Experiment 2}

Ellison and Gotelli (2002) demonstrated that botanical carnivory was only expressed in Sarracenia purpurae when soil nitrogen levels were low. It was possible nutrient levels were too high in the low-nutrient soil plot of Experiment 1 causing Dipsacus not to express botanical carnivory. Thus Experiment 2 compared greater extremes in soil nutrient levels (Fig. 1) with even lower levels of nitrogen, phosphorous, and potassium than in the low-nutrient soil plots in Experiment 1.

On 1 January 2013, soil mixes were prepared for the two $16 \mathrm{~m}^{2}$ greenhouse plots. This experiment was also a 2 × 2 factorial design (high-nutrient soil vs low-nutrient soil) $\mathrm{x}$ (fed vs control). In the high-nutrient plot, a $3 \mathrm{~m}^{3}$ mixture of $1 / 3$ manure, $1 / 3$ compost, $1 / 3$ topsoil, and $2.04 \mathrm{~kg}$ Miracle Grow ${ }^{\mathrm{TM}}$ Standard Plant Fertilizer was added. In the low-nutrient soil plot a $3 \mathrm{~m}^{3}$ mixture of $1 / 4$ play sand, $1 / 4$ vermiculite, $1 / 4$ perlite, and $1 / 4$ topsoil was added. New manure, compost, and topsoil were purchased for this experiment. On 10 January 2013, teasel rosettes greater than $40 \mathrm{~cm}$ dia were planted in each of the two plots. In each, 16 plants were placed in four rows each with four plants. In each row two plants were randomly assigned as controls and two as fed. Soaker hoses kept the soil damp throughout the study ending when s. The first stems began to grow on 1 May 2013. Beginning on 14 May, water was added to the leaf cups of the control plants as they formed. Water was maintained in the leaf cups of the main stem of all control plants during the experiment. A liquefied animal solution was supplied to plants in the fed treatment. This was comprised of two parts earth worms (Lumbricus sp.), two parts adult 
crickets (Gryllus sp.) and one part water pureed in a blender then kept frozen until used. Every two weeks, $15 \mathrm{ml}$ of a prey supplement was added to each leaf cup on the main stem. As stems grew forming more leaf cups, the total amount of prey supplement added also increased.

Caution was taken to prevent any supplement spilling out of leaf cups. The last animal solution was added on 1 September once it appeared the seeds were mature. Soaker hoses were turned off on 1 October, and the dried flower spikes were harvested on 15 November. Flower spikes were stored in large paper bags in a cool, dry laboratory. Seed extraction began in July 2015 following the procedure detailed in Experiment 1. Soil samples were collected August 2013 and sent to the U. K. Regulatory Services for analysis. The seed viability test described in Experiment 1 was used to determine percentage of seeds that germinated for each plant.

\section{Experiment 3}

This experiment examined the potential for botanical carnivory when teasel was grown in a nutrient deprived soil mixture characteristically used for growing carnivorous plants (D'Amato 1998). Twenty plastic pots each containing $19 \mathrm{~L}$ of soil were filled with a soil mixture of $1 / 3$ peat moss, 1/3 silica sand, and 1/3 perlite. Francis Darwin thought it possible that the filaments of teasel leaves might extract nutrients from moisture film that formed on leaves. Consequently in this experiment, caution was taken to prevent any water from contacting leaves. Soil was kept moist by having all pots sit in $10 \mathrm{~cm}$ of water during the experiment. Soaker hoses were not used thus keeping moisture off leaves. On 10 January 2013, one rosette larger than $40 \mathrm{~cm}$ dia was planted in each pot. Half were assigned to the fed treatment, the other half as controls. Soil samples were collected August 2013 and sent to the U. K. Regulatory Services for analysis. Our intended protocol was to add the same animal solution described in Experiment 2 to plants in the 
fed treatment once leaf cups formed. However, by the end of May, no stems were growing from any of the 20 plants. Thus beginning on 1 June, $15 \mathrm{ml}$ of animal solution was added to the center of each rosette of plants in the fed treatment. This was added every seven days until the beginning of July. No water was added to the center of the control plants.

\section{Analysis of invertebrate nutrient supplement samples}

Nutrient content of invertebrate animals used as prey supplement was analyzed at the U. K. Regulatory Services. This included whole crickets from Experiment 1 and the animal solution (liquefied earthworms and crickets) described in Experiment 2. Larvae of blue bottle fly (Calliphora vomitoria) were also analyzed for nutrients. Larvae of this species were used as nutrient supplement by Shaw and Shackleton (2011).

\section{Statistical Analysis}

Statistical analyses were conducted using SPSS (Version 21). Proportional data were transformed by taking the arcsine of the square root, $x=\operatorname{arcsine}(\operatorname{sqrt}(\mathrm{xraw}))$. Seed numbers were $\log$ transformed, $x=\log (\mathrm{xraw}+0.1)$. Independent sample T-tests were used to compare nutrient content between experimental conditions. A two-way ANOVA was used to compare the effect of nutrient content and prey supplementation on seed number and percentage of seed to germinate. Unless otherwise stated, results are presented as the mean and the standard error of the mean. 


\section{Results}

\section{Soil nutrients}

Nitrogen, phosphorus, and potassium were lower in the low-nutrient plot than in the high-nutrient plot in Experiment 1 (Fig. 1). Phosphorus $(t=-5.50, \mathrm{df}=22, p<0.0001)$ and potassium $(t=-8.98, p<0.001)$ were significantly lower, while nitrogen was not $(t=-0.65, \mathrm{df}=$ 22, $p=0.52$ ). Comparing nutrient levels for the high and low-nutrient plots of Experiment 2, nitrogen $(t=-17.336, \mathrm{df}=7, p<0.0001)$, phosphorus $(t=-19.41, \mathrm{df}=7, p<0.0001)$, and potassium $(t=-55.39, \mathrm{df}=7, p<0.0001)$ were significantly lower in the low-nutrient plot (Fig. 1). In comparing soil from the low-nutrient plot of Experiment 2 and soil from Experiment 3 , nitrogen $(t=-9.96, \mathrm{df}=7, p<0.0001)$, phosphorous $(t=-9.32, \mathrm{df}=7, p<0.0001)$, and potassium $(t=-9.79, \mathrm{df}=7, p<0.0001)$ were significantly lower and virtually lacking in the soil of Experiment 3 (Fig. 1).

\section{Nutrient content of whole insects and animal prey solutions}

Shaw and Shackleton (2011) used larvae of blue bottle flies (C. vomitoria) as a nutrient supplement for teasel but did not analyze the nutrient content. We analyzed nitrogen, phosphorus, and potassium for three samples of $C$. vomitoria each containing 144 maggots, 139 maggots, and 138 maggots. From this and based on Shaw and Shackleton (2011) adding 24 maggots to each plant during their study, we estimated these authors provided $58.4 \mathrm{mg}$ of nitrogen, $10.0 \mathrm{mg}$ of phosphorus, and $10.1 \mathrm{mg}$ of potassium to each plant.

Sixty whole crickets were liquefied by U. K. Regulatory Services then analyzed for nutrient content. Crickets were $3.57 \%$ nitrogen, $0.27 \%$ phosphorus, and $0.44 \%$ potassium. Since each plant in the fed treatment was provided 40 crickets during Experiment 1, this resulted 
in $717.6 \mathrm{mg}$ of nitrogen, $53.5 \mathrm{mg}$ of phosphorus, and $89.2 \mathrm{mg}$ of potassium added to each plant as whole crickets. Five samples of animal solution were analyzed. On average these solutions were $1.69 \%$ (range, $1.65 \%$ to $1.71 \%$ ) nitrogen, $0.14 \%$ (range, 0.14 to 0.15 ) phosphorus, and $0.18 \%$ (range, $0.17 \%$ to $0.19 \%$ ) for potassium. Thus for Experiment 2, each plant in the fed treatment received at least $3798 \mathrm{mg}$ of nitrogen, $312 \mathrm{mg}$ of phosphorus, and $409 \mathrm{mg}$ of potassium. In Experiment 3, plants in the fed treatment received $201 \mathrm{mg}$ of nitrogen, $17 \mathrm{mg}$ of phosphorus, and $22 \mathrm{mg}$ of potassium.

\section{Experiment 1}

All 48 plants produced flowers resulting in $1,502,464$ seeds $\left(x^{-}=31,301\right.$ seeds/plant $)$ with a mean of $68.9 \mathrm{~g}$ of seeds/plant. Soil nutrient levels had no significant effect on the number of seeds produced $\left(F_{1,44}=0.001, p=0.979\right.$; Fig. 2$)$, nor did providing crickets as a potential nutrient supplement $\left(F_{1,44}=0.128, p=0.722\right.$; Fig. 2$)$. Soil nutrients had a significant effect on seed germination $\left(F_{1,43}=4.25, p=0.045\right.$; Fig. 3$)$ with a higher percentage of germination of seeds in the low-nutrient plots. Adding crickets did not influence germination $\left(F_{1,43}=0.999, p=\right.$ 0.323; Fig. 3). We found no significant interaction effect between soil nutrients and fed treatment on germination $\left(F_{1,43}=0.747, p=0.392\right)$.

\section{Experiment 2}

A total of 605,341 seeds were produced in this experiment. All plants in the low-nutrient soil flowered, but only 12 of 16 plants produced seeds $\left(x^{-}=7,794\right.$ seeds/plant $)$ with a mean of $15.6 \mathrm{~g}$ of seeds/plant. Two of the four plants not producing seeds in the low-nutrient soil were in the fed treatment. All plants in the high-nutrient soil flowered, and 15 of 16 plants produced 
seeds $(\bar{x}=34,121$ seeds/plant $)$ with a mean of $68.2 \mathrm{~g}$ of seeds/plant. Soil nutrient levels had a significant effect on the number of seeds produced $\left(F_{1,28}=6.508, p=0.016\right.$; Fig. 4), while adding animal solution $\operatorname{did} \operatorname{not}\left(F_{1,28}=0.145, p=0.706\right.$; Fig. 4). We found no significant interaction effect between soil nutrient and fed treatment for seed production $\left(F_{1,28}=0.027, p=\right.$ 0.870). Soil nutrient levels had a significant effect on seed germination $\left(F_{1,23}=5.26, p=0.031\right.$; Fig. 5), with plants in low-nutrient plots having higher percentage germination. Adding animal solution did not influence germination $\left(F_{1,23}=0.373, p=0.547\right.$; Figure 5). We found no significant interaction effect between soil nutrients and fed treatment on germination $\left(F_{1,23}=\right.$ $1.45, p=0.241)$

\section{Experiment 3}

None of the 20 plants grew larger, produced stems or flowered. Instead they remained in rosette form during the experiment. Adding animal solution to the center of the rosettes of the fed group had no influence.

\section{Discussion}

From our three experiments, we found no evidence that D. fullonum growth or reproduction is influenced by adding whole crickets or a liquefied worms and crickets of the animal solution to water-filled leaf cups or to the center of rosettes. Furthermore, our study demonstrated seed production and germination only is influenced by soil nutrients. Moreover when planted in nutrient-free soil characteristic of the mixture in which carnivorous plants are grown, rosettes did not grow, produce stems, or flower when animal solution was added to the center of rosette. 
Botanical carnivory is considered a benefit to both growth and reproduction. We only examined reproduction in the first two experiments because teasel is biennial, dying after setting seed typically in its second year of growth. Growth is an important consideration for perennial species of carnivorous plants as this influences lifetime fitness. Thus for Dipsacus, an increase in the number and quality of seeds is the only measurable benefit from carnivory.

Dipsacus fullonum (like other species of Dipsacus) lacks characteristics typical of most carnivorous plants. It is a large species (more than $2 \mathrm{~m}$ tall) that grows quickly in its second year. It grows in both wet and dry nitrogen enriched soil and has a large, well-developed root system. The only similarity to carnivorous plants is that leaves hold water in which invertebrates accumulate similar to five genera of carnivorous pitcher plants.

Our conclusion that D. fullonum is not carnivorous differs from that drawn by Shaw and Shackleton (2011). These authors did not analyze the soil nutrients at their study site or the amount of nutrients in the fly larvae they provided plants, but estimated $33 \mathrm{mg}$ of nitrogen was provided to their plants during the study. We estimated the amount of nitrogen these authors provided by direct analysis of larvae from the same species of fly. Shaw and Shackleton (2011) added 24 larvae to each fed plant over the period of the experiment. We estimate this to be the addition of $58.4 \mathrm{mg}$ of nitrogen for each plant. By using our higher estimate for comparison, we provided 12.3 times more nitrogen in Experiment 1, 65.0 times more in Experiment 2, and 3.4 times more in Experiment 3. Despite this, the supplemental nutrients we provided with crickets or animal solution did not influence seed production.

In Kentucky, D. fullonum is relatively small when it grows on hot, dry slopes along roadsides, but can be extremely large when it grows in wet, nutrient rich soil along streams. The plants in our experiment were grown in moist soil in a hot, humid greenhouse. These optimal 
conditions were intended to maximize the plants uptake of nutrients under conditions where they grow to their maximum size. Our assumption for these growing conditions was to maximize the potential to draw from an additional nutrient source such as dead animals in the leaf cups. The growing conditions in our study were likely much different from those of Shaw and Shackleton (2011), as our plants were much larger and produced more seeds. Seed mass from these authors' site 2 averaged 9.0g while our mean was $68.9 \mathrm{~g}$ in Experiment 1 and 68.2 grams in the highnutrient treatment in Experiment 2. Furthermore our mean seed mass from Experiment 2 was $119 \%$ greater than the dried biomass of the entire above-ground plant from s insect fed treatment. It is difficult to say how extreme differences in plant sizes between the two studies may have influenced the different results. Some species of carnivorous plants have mutualistic organisms that digest the prey into chemical forms then more readily taken up by the plants (Anderson and Midgley 2003; Nishi et al. 21013). Since D. fullonum is non-native to North America, but native to Great Britain, it is possible mutualistic organisms co-exists with Dipsacus in Great Britain and are missing from plant growing in North America where they are exotic.

Three hypotheses for the function of water-holding leaf cups of teasel were discussed by Christy (1923): 1) water reservoirs; 2) botanical carnivory for extracting nutrients from captured invertebrates; and 3) barriers preventing harmful insects from climbing stems. In Kentucky, teasel cups hold water for a few days after a rain but not for much of the growing season when rain is lacking. Christy (1923) made the same observation for teasel in Great Britain where it is native, thus we agree that cups do not function as water reservoirs during dry periods. Darwin (1877), Christy (1923), and most recently Shaw and Shackleton (2011) considered the function of cups for capturing prey and extracting nutrients. Since we found no evidence of this, we feel the third function must be considered. 
The hypothesis that cups are a defense against herbivory has received no experimental consideration that we are aware. Leaves, stems, and flower spikes of D. fullonum are covered with prickles and spines. The adaptation of these seems most likely defense against herbivores attempting to eat any part of the plant. So too, the water-filled cups could prevent herbivorous insects, snails, or slugs from crawling up stems to leaves and flowers. Currently we have grown five species of teasel. Of these, the four species covered with prickles and spines also formed leaf cups (D. fullonum, D. ferox, D. laciniatus, and D. sativus). Dipsacus pilosus was the only species of the five that did not form leaf cups. It also had fewer prickles that were short and relatively soft. This suggests some single adaptation shared by both prickles and leaf cups. Francis Darwin noted that prickles occur on the stems above the maximum water level in cups. He suggested this prevented trapped insects from using prickles to crawl out of the water. This could be an adaptation as a barrier against herbivorous invertebrates. We also found prickles starting above the maximum water level in cups in the four prickly species of Dipsacus.

The cup plant (Silphium perfoliatum) is a perennial and the only North American member of its genus with leaves that form water-holding cups. Like Dipsacus, water held by these leaves typically contains dead and decomposing insects (Krupa pers. obs.). In fact we see more decayed insects in cups of $S$. perfoliatum than for the two species of Dipsacus in Kentucky (D. fullonum and the cut-leaf teasel, D. laciniatus). Also, cups of all three species are empty during dry periods from June to August. Cup plants have small, dense, stiff hairs on their leaves but lack prickles. Otherwise this species is generally similar to D. fullonum morphologically. Despite this, we are not aware of any discussion that $S$. perfoliatum might be carnivorous. The most likely explanation is that the cups of both Dipsacus and Silphium have the same function, possibly herbivore defense or some other function of which we are not aware. 
Like Dipsacus, species of Devil's claw (Ibicella lutea and Proboscidea parviflora) have long been suspected to be carnivorous because they too capture insects. For the latter two genera, their glandular sticky leaf surfaces (Plachno et al. 2009) accumulate insects. However, Plachno et al. (2009) determined these two species did not take up nitrogen, phosphorous, potassium or magnesium. They concluded the sticky leaf surfaces evolved as defense against herbivorous animals. Thus like Ibicella and Proboscidea, the structures of Dispacus (and possibly $S$. perfolitum) may have evolved as defenses against herbivores.

In conclusion, we found no evidence that $D$. fullonum is capable of foliar absorption of nutrients. We found that growth and reproduction were influenced by soil nutrients alone. Thus we do not feel Dipsacus can be considered a carnivorous plant by any existing definition of botanical carnivory. The question remains; what is the adaptation of leaves that form waterholding cups such as many species of Dipsacus and S. perfoliatum? Although Christy (1923) dismissed these as adaptations protecting plants from herbivory, we feel this should be examined further as the most plausible hypothesis. If this is not the case, other functions must exist that have yet to be considered. The second related question remains; what is the function of the filamentous protuberances both Darwin (1878) and Christy (1923) observed in the D. fullonum and Darwin observed in D. pilosus? If these are for capturing nitrogen, might this be from ammonia in the surrounding air rather than from dead prey as Darwin (1877) suggested?

\section{Acknowledgments}

We thank Tim Philips for use of his equipment and his help on this project. We also thank Carol and Jerry Baskin for their helpful comments and suggestions throughout this study. 
We thank the staff at the University of Kentucky Regulatory Services for conducting analysis of soil nutrients and for doing the viability tests for seed germination.

\section{References}

Adlassnig, W., Lendl, T., Peroutka, M., and Lang, I. 2010. Deadly glue-adhesive traps of carnivorous plants. In Biological adhesive systems. Edited by J. von Byern and I. Grunwald. Springer Vienna, New York, pp. 15-28.

Anderson, B., and Midgley, J. J. 2003. Digestive mutualism, an alternate pathway in plant carnivory. Oikos, 102(1):221-224. doi:10.1034/j.1600-0706.20

Büsgen, M. 1883. Die bedeutung des insektenfanges fur Drosera rotundifolia. Bot. Zeit. 41:569$577,585-594$.

Christy, M. 1923. The common teasel as a carnivorous plant. J. Bot. 61:33-45.

D’Amato, P. 1998. The savage garden: cultivating carnivorous plants. Ten Speed Press, Berkeley.

Darnowski, D.W., Carroll, D.M., Płachno, B, Kabanoff, E., and Cinnamon, E. 2006. Evidence of protocarnivory in triggerplants (Stylidium spp.; Stylidiaceae). Plant Biol. 8(6):805-812. $\underline{\text { doi:10.1055/s-2006-924472 }}$

Darwin, C. 1875. Insectivorous Plants. Appleton and Company, New York.

Darwin, F. 1877. On the protrusion of protoplasmic filaments from the glandular hairs on the leaves of the common teasel (Dipsacus sylvesrtis). Quart. J. Microsc. Sci. 17:245-272.

Darwin, F. 1878. Experiments on the nutrition of Drosera rotundifolia. J. Linn. Soc. Bot. 17:1732. 
Ellison, A.M. 2006. Nutrient limitation and stoichiometry of carnivorous plants. Plant Biol. 8(6):740-747. doi:10.1055/s-2006-923956

Ellison, A.M., and Gotelli, N.J. 2002. Nitrogen availability alters the expression of carnivory in the northern pitcher plant, Sarracenia purpurea. Proc. Natl. Acad. Sci. U.S.A. 99(7):4409-4412. doi:10.1073/pnas.022057199

Givnish, T.J., Burkhardt, E.L., Happel, R.E., and Weintraub, J.D. 1984. Carnivory in the bromeliad Brocchinia reducta, with a cost-benefit model for the general restriction of carnivorous plants to sunny moist, nutrient-poor habitats. Am. Nat. 124(4):479-497. $\underline{\text { doi:10.1086/284289 }}$

Jennings, D.E., Krupa, J.J., Raffel, T.R., and Rohr, J.R. 2010. Evidence for competition between carnivorous plants and spiders. Proc. R. Soc. Lond. B Biol. Sci. 277:001-3008. $\underline{\text { doi:10.1098/rspb.2010.0465 }}$

Juniper, B.E., Robins, R.J., and Joel, D.M. 1989. The carnivorous plants. Academic Press, London.

Kellerman, C., and von Raumer, E. 1878. Vegatationsversuche an Drosera rotundifolia, mit und ohne fleischfutterung. Bot. Zeit. 36:209-218, 225-229.

Nge, F.J., and Lambers, H. 2018. Reassessing protocarnivory-how hungry are triggerplants? Aust. J. Bot. 66(4):325-330. doi:10.1071/bt18059

Nishi, A.H., Vasconcellos-Neto, J., and Romero, G.Q. 2012. The role of multiple partners in a digestive mutualism with a protocarnivorous plant. Ann. Bot. 111(1):143-150. $\underline{\text { doi:10.1093/aob/mes242 }}$ 
Pavlovič, A., Krausko, M., Libiaková, M., and Adamec, L. 2014. Feeding on prey increases photosynthetic efficiency in the carnivorous sundew Drosera capensis. Ann. Bot. 113(1):69-78. doi:10.1093/aob/mct254

Plachno, B. J., Adamec, L., and Huet, H. 2009. Mineral nutrient uptake from prey and glandular phosphatase activity as a dual test of carnivory in semi-desert plants with glandular leaves suspected of carnivory. Ann. Bot. 104(4):649-654. doi:10.1093/aob/mcp155

Rice, B.A. 2006. Growing carnivorous plants. Timber Press, Portland, Oregon.

Shaw, P.J.A., and Shackleton, K. 2011. Carnivory in the teasel Dipsacus fullonum - The effect of experimental feeding on growth and seed set. Plos One, 6(3):e17935. doi:10.1371/journal.pone.0017935

Schnell, D.E. 2002. Carnivorous plants of the United States and Canada. Timber Press, Portland, Oregon.

Spomer, G.G. 1999. Evidence of protocarnivorous capabilities in Geranium viscosissimum and Potentilla arguta and other sticky plants. Int. J. Plant Sci. 160(1):98-101. $\underline{\text { doi:10.1086/314109 }}$

Turner, W. 1568. A New Herball. Arnold Barckman, Cologne.

Werner, P.A. 1975. Predictions of fate from rosette size in tease (Dipsacus fullonum L.). Oecologia, 20(3):197-201. 


\section{Figure Legends:}

Fig. 1. Mean soil nutrient levels of total nitrogen, and available phosphorous and potassium measured as ppm with standard errors for the three experiments $(n=12$ for Experiment $1 ; n=5$ for Experiment 2; $n=4$ for Experiment 3).

Fig. 2. Mean number of seeds produced with standard errors from Experiment 1 for high $(n=$ $24)$ and low-nutrient $(n=24)$ soil plots and for plants provided prey supplements in the fed treatment and controls. Soil nutrients and providing insects had no significant effect $(p=0.979$ and $p=0.722$, respectively).

Fig 3. Mean percent germination with standard errors from Experiment 1 for high and lownutrient soil plots and for plants provided prey supplements in the fed treatment and controls (4 replications each with 25 seeds). Soil nutrients had a significant effect on germination ( $p=$ $0.045)$, while providing insects did not $(p=0.979$ and $p=0.323)$.

Fig. 4. Mean number of seeds produced with standard errors from Experiment 2 for high $(n=$ $15)$ and low-nutrient $(n=12)$ soil plots and for plants provided prey supplements in the fed treatment and controls. Soil nutrients had a significant effect on number of seeds produced $(p=$ 0.016), while providing animal solution did not $(p=0.706)$.

Fig. 5. Mean percent germination with standard errors from Experiment 2 for high and lownutrient soil plots and for plants provided prey supplements and controls (4 replications each with 25 seeds). Soil nutrients had a significant effect on germination $(p=0.031)$, while providing animal solution did not $(p=0.241)$. 


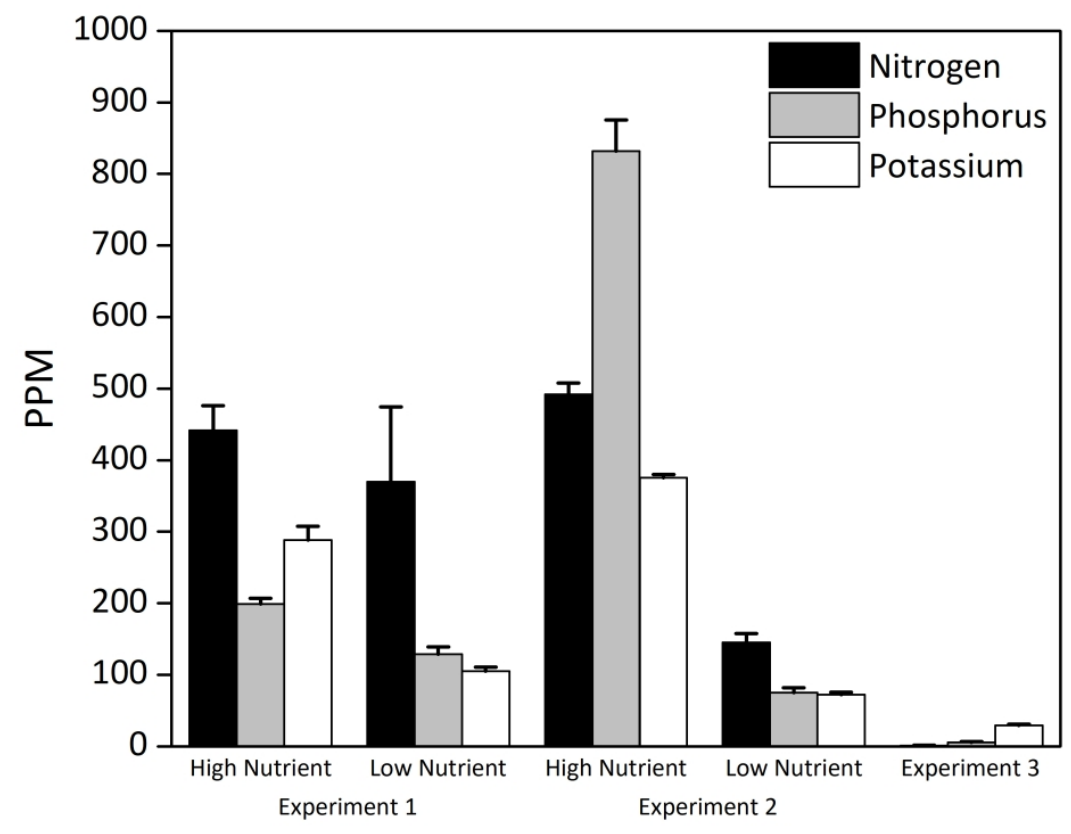

Figure 1

$272 \times 208 \mathrm{~mm}(300 \times 300$ DPI) 


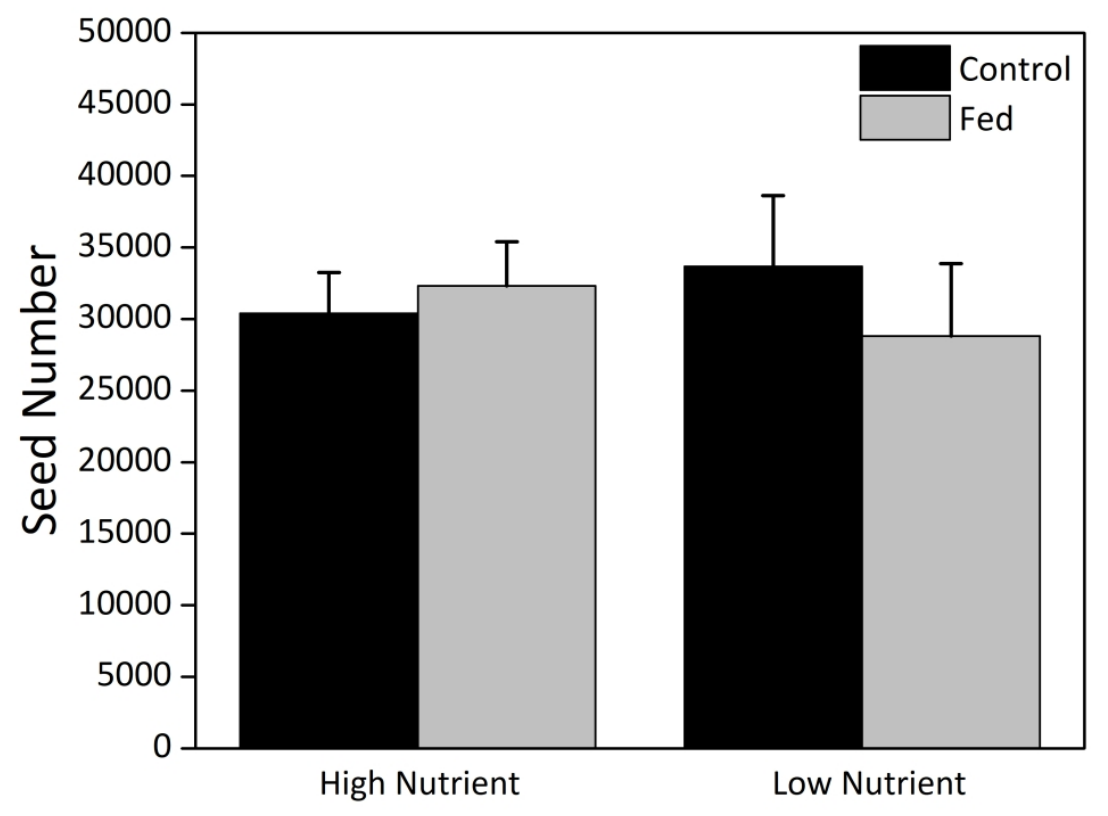

Figure 2

$272 \times 208 \mathrm{~mm}(300 \times 300$ DPI $)$ 


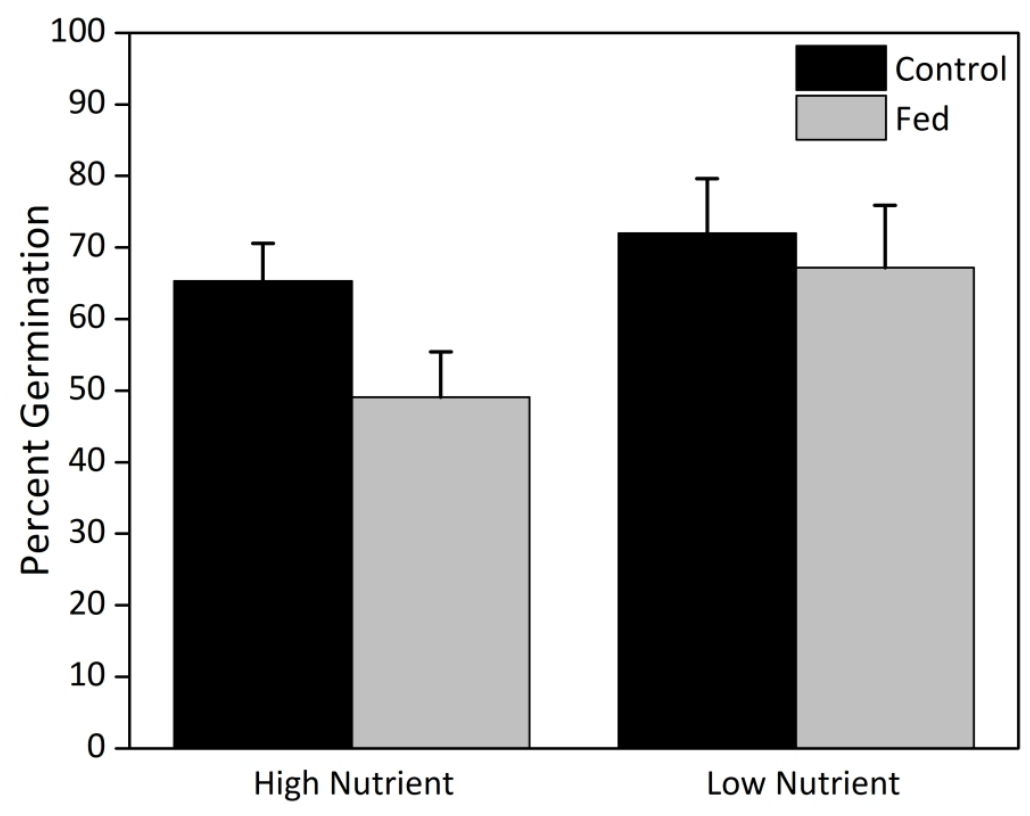

Figure 3

$272 \times 208 \mathrm{~mm}(300 \times 300$ DPI $)$ 


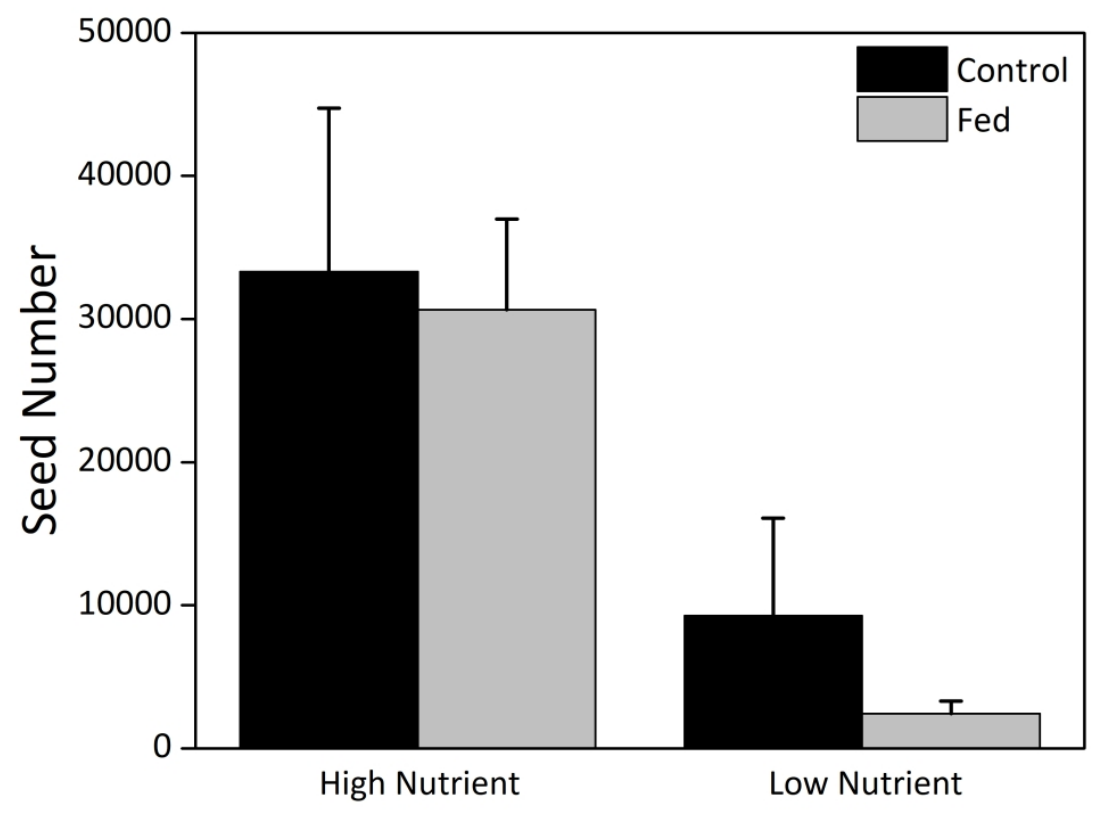

Figure 4 $272 \times 208 \mathrm{~mm}(300 \times 300$ DPI $)$ 


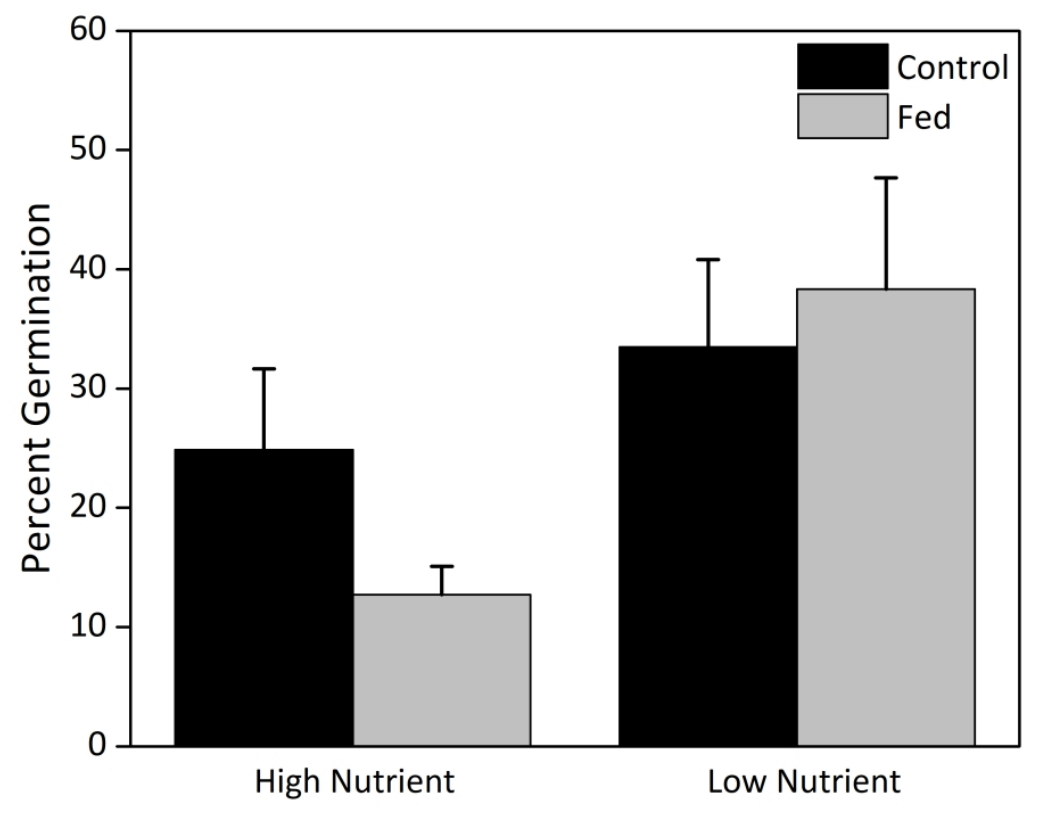

Figure 5

$272 \times 208 \mathrm{~mm}(300 \times 300 \mathrm{DPI})$ 